\title{
THE EFFECT OF COOPERATIVE LEARNING MODEL GROUP INVESTIGATION TYPE TOWARD STUDENTS' LEARNING OUTCOME ON VIBRATION AND WAVE SUBJECT GRADE VIII SMP NEGERI 1 LUBUK PAKAM ACADEMIC YEAR $2013 / 2014$
}

\author{
James Wilson and Ridwan Abd. Sani \\ Jurusan Fisika FMIPA Universitas Negeri Medan \\ Jalan Willem Iskandar Pasar V Medan, Sumatera Utara \\ JWMANUNGKALIT@gmail.com
}

\begin{abstract}
The purpose of this research is: to know the students' learning outcome and the effect of cooperative learning model group investigation type toward students' learning outcome on vibration and wave subject grade viii SMP Negeri 1 Lubuk Pakam Academic Year 2013/2014. The research method was quasi experiment. The population was all students at class VIII SMP N 1 Lubuk Pakam semester II consist of 8 classes. This research sample use two classes consist of 38 students, class VIII-A as experimental class and class VIII-D as control class and define by cluster random sampling. The data was normal distribution and homogeneity. The result that was obtained: The average value in experimental class after given treatment is 6.750 and the average value in control class after given treatment is 5.697 . So it can be concluded that the students' learning outcome using cooperative learning model group investigation type is better than conventional learning on vibration and wave subject grade VIII SMP Negeri 1 Lubuk Pakam academic year 2013/2014.
\end{abstract}

Keyword : Group Investigation Model, Students' Learning Outcome, The Effect Of Group Investigation Model, and Conventional Learning Model.

\section{INTRODUCTION}

Education is very important for everyone anywhere and anytime. Education is one way to change the fate. Through education every person will get the ability to competitive. In the Sanjaya (2009:2) stated that UU No. 20 of 2003 about National Education System said education is a planned conscious effort to create learning condition and learning process so that learners are actively to develop their potential for spiritual strengthen such as religious, self- control, good personality, good intelligence, good character and skills for state and nation. Realize this, the government is very serious about education, because through a good education system expected to appear next qualified generation and able to adjust to survive for living in society, state and nation.

And then, the Government in the Ministry of Education and Culture issued curriculum 2013 with the theme "curriculum can produce Indonesian people which productive, 
creative, innovative and affective through the strengthen integrated attitude, skill and knowledge". Government believed the curriculum 2013 as a way to overcome the problem education in this country. The presence of curriculum 2013 aimed to make the young generations more active, creative, have good skill and attitude and also intelligence young generation who can answer the challenge of globalization era, so that they can competitive nationally and internationally. The curriculum 2013 requires students to be useful in skill, attitude and knowledge in society for state and nation.

In the school, teacher is the most influential stakeholders toward the quality and ability of student, because teacher is interact and communicate directly to the student. Students are educated by teacher at school every day. The ability of teacher to educate is very influential to success or failure the learning activities (KBM) at schools. For the teacher must be able to present learning activities more active, creative, and fun to get golden generation in the future. So, it can be conclude the education is very important and key to be success state and nation.

Physics is natural science, phenomenon, and concept. So, the researcher try to take the learning model connected to natural phenomenon. Based on observation data done by researcher on February 08 ${ }^{\text {th }} 2014$ to class VIII-A and VIII-D in SMP Negeri 1 Lubuk Pakam from 70 students got the students interest to physics learning is $44.02 \%$. From the questionnaire found that $40 \%$ of students stated physics is a difficult and less interest subject, $50 \%$ of students stated physics is an ordinary subject, $5.71 \%$ of students stated physics is a bored subject, and only $4.29 \%$ of students stated physics is easy and fun subject. From the questionnaire data also found that just $22.86 \%$ teacher make group discussion in the class, so the students seldom to do team work in learning process. And then, when researcher ask the students in the class only $\pm 35.71 \%$ from 70 of students pass the physical exam and the others are still under KKM. From the data above, researcher know that students' interest toward physics subject is low and need to be increased.

Based on interview with natural science teacher Mahmud that teach in SMP Negeri 1 Lubuk Pakam on February 8th 2014, said that learning outcome of students in physics still low that is $50 \%$ in class VIII , this case look from daily test, daily activity in the class, homework, mid semester and semester test of the students. Several factors cause the low average value of students' learning outcome that is the teacher not use variation of the learning model or just use conventional model, less allow optimum use of learning media, and the interest of students to physics is low. In addition, teachers are also less linking subject matter in daily life, which is $42.86 \%$ of students stated that the teachers connect materials to daily life only in early material. From the observation, researcher can conclude that the learning process dominated by teacher and still use lecture, question and answer, and discussion method. It is spoken by Dimyati and Mudjiono (2009:117) domination of teacher in learning process cause the students more passively, students more waiting for serving from the teacher than find their own knowledge, skill 
and attitude. The teacher made as source of information, so finally the students more passive and just listen the teacher explanation in learning activities. This condition can be make the students bored and cause the students understanding toward physical concept is low, this situation make physics is difficult and bored subject.

From the problem above the researcher has reason to take Cooperative Learning Model Group Investigation Type on subject Vibration and Wave. According to Istarani (2012 : 86) says that Group Investigation is learning with group model, every students make in several group for solve the physics problem. So, researcher do Cooperative Learning Model Group Investigation Type to increase students' learning outcome.

Based on explanation above, with Group Investigation researcher interest to do research about "The Effect of Cooperative Learning Model Group Investigation Type Toward Students' Learning Outcome on Vibration and Wave Subject Grade VIII SMP Negeri 1 Lubuk Pakam Academic Year 2013/2014."

\section{RESEARCH METHOD}

The research has been done at Junior High School (SMP Negeri) 1 Lubuk Pakam. The populations of this research are all of students in VII grade SMP Negeri 1 Tebing Tinggi that consist of 8 classes with each class consist of $38-40$ students. The sample is choosen by cluster random sampling. The sample is divided into two classes consisting of one class as experimental class and the other class as control class.

This research is involved two different treatments for the experimental class and the control class, where the two classes are treated differently. The experimental class treated with cooperative learning model group investigation type and the control class treated with conventional learning model.

To determine the student's understanding of the concept, researcher use test on both classes before and after treatment, which are called pretest and posttest.. The design of the research is as follows:

Table 1 Design of Research

\begin{tabular}{|l|c|c|c|}
\hline \multicolumn{1}{|c|}{ Class } & Pretest & Treatment & Posttest \\
\hline Experiment & $\mathrm{T}_{1}$ & $X_{1}$ & $\mathrm{~T}_{2}$ \\
\hline Control & $\mathrm{T}_{1}$ & $X_{2}$ & $\mathrm{~T}_{2}$ \\
\hline
\end{tabular}

Description :

$\mathrm{T}_{1}=$ Pretest

$\mathrm{T}_{2}=$ Posttest

$X_{1}=$ Learning using cooperatve learning model group investigation type

$X 2$ = Learning using conventional learning model

The selection of data is carried out to observe whether the samples come from normal distribution population or not. The test used is Liliefors test and Homogeneity test, to know the homogenity of both samples used formula as follows (Sudjana, 2008 : 249) :

$$
F_{\text {count }}=\frac{S_{1}^{2}}{S_{2}{ }^{2}}
$$

Description:

$S_{1}^{2}=$ Biggest Variance Data

$S_{2}{ }^{2}=$ Smallest Variance Data

The test criteria are received Ho: the data come from a homogeneous population if $\mathrm{F}$ count $<\mathrm{F}$ table, where the $\mathrm{F}$ table obtained from the distribution list $\mathrm{F}$ with $\mathrm{a}=0.05$. Here $\mathrm{a}$ is a real level for testing. 
Hypothesis test use t-test with formula (Sudjana, 2008: 239) :

$$
t=\frac{\bar{x}_{1}-\bar{x}_{2}}{S \sqrt{\frac{1}{n_{1}}+\frac{1}{n_{2}}}}
$$

$\mathrm{S}$ is combination of standard deviation can be calculated with formula :

Where:

$$
S^{2}=\frac{\left(n_{1}-1\right) S_{1}^{2}+\left(n_{2}-1\right) S_{2}^{2}}{n_{1}+n_{2}-2}
$$

$\bar{x}_{1}=$ Average value in experimental class.

$\bar{x}_{2}=$ Average value in control class.

$n_{1}=$ Total of sample in experimental class.

$n_{2}=$ Total of sample in control class.

$S^{2}=$ Variance

$S_{1}^{2}=$ Variance in experimental class

$S_{2}{ }^{2}=$ Variance in control class

$\mathrm{t}=\mathrm{t}$ distribution

Testing Criteria : $\mathrm{H}_{\mathrm{o}}$ accept if $\mathrm{t}_{\text {calculate }}$ $<\mathrm{t}_{(1-\alpha)}$ where $\mathrm{t}{ }_{(1-\alpha)}-\alpha$ get from distribution table $\mathrm{t}$ with independent degree $(\mathrm{dk})=\mathrm{n}_{1}+\mathrm{n}_{2}-2$ and the probability $(1-\alpha)$ with $\alpha=0,05$ for another value of $\mathrm{t} \mathrm{H}_{\mathrm{o}}$ not accept, so Cooperative Learning Model Group Investigation Type has influence to the student's achievement in learning physics.

\section{RESULT OF RESEARCH}

Based on data, the pre-test of student in experiment and control class in score range from 0 until 10 , and got the mean of pre test score in experiment class is 4.566 with the deviation standard of 1.034 while mean pre-test score in control class is 4.316 with deviation standard of 1.062 .

The experiment class with treatment using Cooperative
Learning Model Group Investigation

Type has mean score is 6.75 with deviation standard of 0.845 . While in control class after given treatment with Direct Instructional Model has mean post test score is 5.697 with deviation standard of 1.095 .

The results of hypothesis testing one tail on the post-test with $a=0.05$ obtained the score $t_{\text {count }}=4.681$ and $\mathrm{t}_{\text {table }}=1.668$. By comparing $\mathrm{t}_{\text {count }}$ and $t_{\text {table }}$ obtained $t_{\text {count }}>t_{\text {table }}$ it's $4.681>$ 1.668 so Ha accepted. It can be conclude that cooperative learning model group investigation type has effect on student's learning outcome on vibration and wave subject grade VII SMP N 1 Lubuk Pakam academic year 2013/2014.

The students' learning outcome of cognitive test shows that the average score of pretest in the experimental class is 4.566 with deviation standard of 1.034 and the average posttest value is 6.75 with deviation standard of 0.845 . While the values obtained in the control class average pretest is 4.316 with deviation standard of 1.062 and the average posttest value is 5.697 with deviation standard of 1.095. From the data, average posttest value in experimental class is greater than control class. The increasing of posttest value is caused by the treatment given to the students. In experimental class given treatment using cooperative learning model group investigation type and control class given the treatment using conventional learning model.

The implementation of Cooperative Learning Model Group Investigation Type is the students more active in learning process. In Cooperative Learning Model Group Investigation Type the students do team work or cooperation in his 
group. One students help his friend (the clever students help the stupid or lazy students) to take the understanding and investigating about topic. Syamsuri Hasan in his journal (2011:197) learning model group investigation showed satisfactory results. Learners are usually passive in learning activities, become more active and more brave in asking or answering questions from teachers and peers. Learners can enhance cooperation within the group during the learning activities, participate in discussion to solve the problem, responsible for carrying out practical tasks that it provides, presented the results of the working group, as well as the seriousness of the orderly carrying out evaluation tests. So, Cooperative Learning Model Group Investigation Type with team work priority is better than conventional learning.

In hypothesis test showed that the different increasing of student's learning outcomes in experiment and control class. The student's learning outcomes is better in experiment class. So, can be concluded that there is an effect of Cooperative Learning Model Group Investigation Type Toward Students' Learning Outcome on Vibration and Wave Subject Grade VIII SMP Negeri 1 Lubuk Pakam Academic Year 2013/2014.

$$
\text { The research }
$$

about

Cooperative Learning Model Group Investigation has been researched by Dedi Suhendri (408121036), The result of pretest in experiment class is 41,88 and 42,81 in control class. After given the treatment for each class got the average postest by Group Investigation is 80,31 where as in Conventional Model is 75,63. From this research the Group investigation have effect toward students' learning outcome on calor subject grade VII semester I SMP IT Al-Fityan Medan T.P 2012/2013.

Although the Cooperative Learning Model Group Investigation Type could improve students' learning outcome, but during in teaching and learning process the Guided Discovery Learning Model has the disadvantage, so for the next researcher should use the time effectively in cooperative learning model group investigation type to increase students' learning outcome, should give more attention and guidance to students who passive in the learning process and do the best strategy using cooperative learning model group investigation type to make this research more better.

\section{CONCLUSION}

Based on the research result, data analysis, and discussion can be concluded that:

The students' learning outcome after give the treatment of Cooperative Learning Model Group Investigation Type in experiment class 6.750 and in control class with treatment Conventional Model is 5.697 and there is an effect of students' learning outcome with treatment of Cooperative Learning Model Group Investigation Type and Conventional Model Toward Students' Learning Outcome

\section{SUGGESTION}

Based on the research result and discussion before, researcher give suggestions as follows:

Should use the time effectively in cooperative learning model group investigation type to increase students' learning outcome, should give more attention and guidance to students who passive in the learning 
process, do the best strategy using cooperative learning model group investigation type to make this research more better, must be have ability to know the students' characteristic to make the learning process using cooperative learning model group investigation type more better, must be know the facilities of school to support the successfull of this research, take full documentation for every steps in learning process by using cooperative learning model group investigation type to make this research more better, in school can use this model to make student more active, brave, cooperation in group and have responsibilty toward the task in learning process to increase sudents' learning outcome.

\section{Refferences}

Arends, Richard I., 2008, Learning to Teach, New York, McGraw Hill Companies, Inc.

Asmani, Jamal Ma'mur, 2012, 7 Tips Aplikasi PAKEM, Jogjakarta, Diva Press.

Azwar, 2013, The Effect of Contextual Teaching and Learning by using Flash Animation Media In Subject Matter Vibration and Wave on Grade XII SMA Negeri 2 Kisaran Year 2012/2013, Skripsi, Medan, FMIPA Unimed.

Bern, Robert G dan Patricia M. Erickson, 2001, National Commission Career and Technical Education, Contextual Teaching and Learning Preparing Students For The New Economy, Volume 5 halaman 2.

Dimyati dan Mudjiono, (2009), Belajar dan Pembelajaran, Jakarta, Rineka Cipta.
Hasan, Syamsuri, 2011, Jurnal Pendidikan, Model Cooperative Learning Tipe Group Investigation Untuk Meningkatkan Hasil Belajar Pada Mata Pelajaran Perawatan Dan Perbaikan Sistem Refrigerasi, Volume VII dan halaman 197.

Istarani, 2012, 58 Model Pembelajaran Inovatif, Medan, Media Persada.

Kanginan, Marthen, 2007, IPA Fisika Untuk SMP Kelas VIII, Jakarta, Erlangga.

Krisno, agus dkk., 2008, IPA Fisika SMP dan MTs untuk kelas VIII, Jakarta, Pusat

Perbukuan Depertemen Pendidikan Nasional.

Lumbanraja, Ridola, 2012, Pengaruh Pendekatan Kontekstual dengan Metode Demonstrasi terhadap Peningkatan Hasil Belajar Kimia Larutan Elektrolit dan Nonelektrolit Pada Siswa Kelas X SMA, Skripsi, Medan, FMIPA Unimed.

Pratiwi, Rinie dkk., 2008, Contextual Teaching and Learning IPA untuk kelas VIII, Jakarta, Pusat Perbukuan Depertemen Pendidikan Nasional.

Sani, Ridwan Abdullah, 2013, Inovasi Pembelajaran, Jakarta, Bumi Aksara.

Sanjaya, Wina, 2009, Strategi Pembelajaran, Jakarta, Kencana Prenada Media Group.

Sihono, Teguh, 2004, Jurnal Pendidikan dan Ekonomi, Contextual Teaching and Learning Sebagai Model Pembelajaran Ekonomi Dalam KBK, Volume 1 dan halaman 75 . 
Sudjana, 2008, Metoda Statistika, Bandung, Tarsito.

Suhendri, Dedi, 2012, Pengaruh Model Pembelajaran Kooperatif Tipe Kelompok Investigasi (Group Investigation) terhadap Hasil Belajar Siswa pada Materi Pokok Kalor Kelas VII semester 1 SMP It Al-Fityan Medan Tahun 2012/2013, Skripsi, Medan, FMIPA Unimed.

Sukabdiyah, Srie, 2011, Sain Fisika 1 SMP Kelas VII, Jakarta, Yudhistira.

Trianto, 2010, Mendesain Model Pembelajaran InovatifProgresif, Jakarta, Kencana Prenada Media Group.

Wasis dkk., (2008), IPA Fisika SMP dan MTs untuk kelas VIII, Jakarta, Pusat

Perbukuan Depertemen Pendidikan Nasional.

Wau, Yasaratodo, 2013, Profesi Kependidikan, Medan, Unimed Press. 